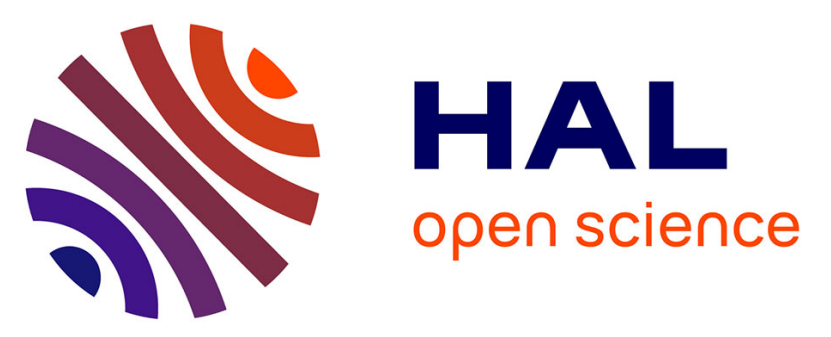

\title{
Recent dynamic studies on the middle atmosphere at mid- and low-latitudes using Rayleigh Lidar and other technologies
}

\author{
Alain Hauchecorne, Sergey Khaykin, Philippe Keckhut, Nahoudha Mzé, \\ Guillaume Angot, Chantal Claud
}

\section{To cite this version:}

Alain Hauchecorne, Sergey Khaykin, Philippe Keckhut, Nahoudha Mzé, Guillaume Angot, et al.. Recent dynamic studies on the middle atmosphere at mid- and low-latitudes using Rayleigh Lidar and other technologies. Le Pichon, Alexis, Blanc, Elisabeth, Hauchecorne, Alain (Eds.). Infrasound Monitoring for Atmospheric Studies, Springer, pp.757, 2019, 978-3-319-75138-2. insu-01876822

\section{HAL Id: insu-01876822 \\ https://hal-insu.archives-ouvertes.fr/insu-01876822}

Submitted on 20 Sep 2018

HAL is a multi-disciplinary open access archive for the deposit and dissemination of scientific research documents, whether they are published or not. The documents may come from teaching and research institutions in France or abroad, or from public or private research centers.
L'archive ouverte pluridisciplinaire HAL, est destinée au dépôt et à la diffusion de documents scientifiques de niveau recherche, publiés ou non, émanant des établissements d'enseignement et de recherche français ou étrangers, des laboratoires publics ou privés. 


\title{
Recent dynamic studies on the middle atmosphere at mid- and low-latitudes using Rayleigh Lidar and other technologies
}

\author{
Alain Hauchecorne, Sergey Khaykin, Philippe Keckhut, Nahoudha Mzé, Guillaume \\ Angot, and Chantal Claud
}

\section{Introduction}

The middle atmosphere is the region of the atmosphere between about 12 and $90 \mathrm{~km}$ above the troposphere where clouds are formed and below the thermosphere strongly controlled by the solar radiation. It is divided into two main layers defined by their vertical gradient of temperature (Fig 1). The stratosphere with a positive temperature gradient extends from 12 to $48 \mathrm{~km}$. This is the region where the ozone layer is formed, protecting us against the harmful UV solar radiation. The mesosphere with a negative temperature gradient is located between 48 and $90 \mathrm{~km}$. This is a region very dynamically active. The vertical structure of the middle atmosphere is mainly driven by the absorption of solar radiation by ozone, which is maximum at the stratopause defining the limit between the two layers. However the meridional structure of the temperature field is far from the radiative equilibrium, especially in the upper mesosphere where the coldest temperatures are reached at the summer pole with 24 hour per day of solar illumination (Fig. 2). The meridional-vertical structure of the middle atmospheric temperature field can only be explained if we take into account the dynamics that transports air masses, energy and momentum flux between the different parts of the atmosphere. In the stratosphere, the main meridional-vertical dynamical feature is the Brewer Dobson circulation (Shepherd 2000) with an ascending branch in the equatorial region, a meridional transport from the equator to the poles and a descending branch in the polar region. In the mesosphere the main circulation is from the summer pole to the winter pole, with an ascent (descent) of air and an adiabatic cooling (warming) at the summer (winter) pole. For more explanations see Hauchecorne et al. (2010). 


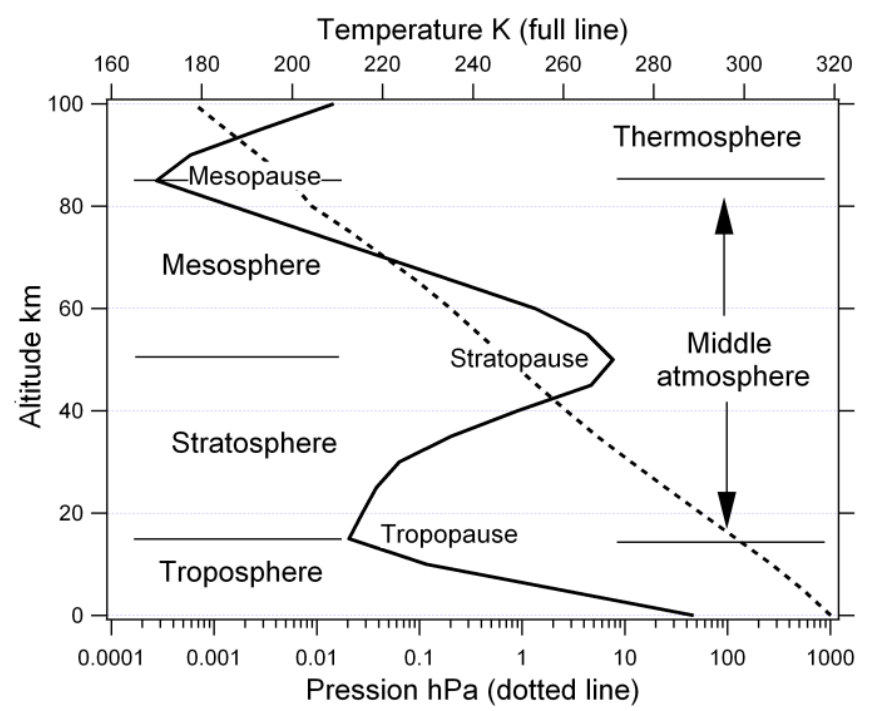

Fig. 1 Schematic representation of the vertical profile of atmospheric temperature and pressure showing the separation between different atmospheric layers. The middle atmosphere includes the stratosphere and the mesosphere. From Hauchecorne et al. (2010).

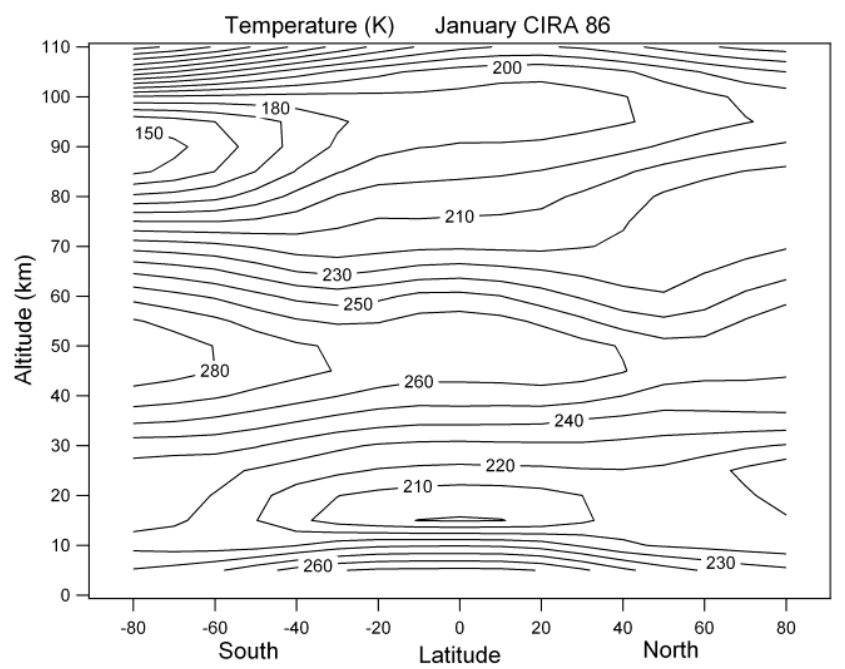

Fig. 2 Zonally averaged temperature (K) from the surface to approximately $120 \mathrm{~km}$ altitude in January, based on CIRA 86 (Fleming et al., 1988).

Atmospheric waves are known to play a major role in the energy and momentum budget of the middle atmosphere, and their influences on the atmospheric structure and circulation have been widely recognized (e.g. Andrews, 1987; Fritts and Alexander, 2003). Atmospheric waves carry energy and momentum from one region to another. It is crucial to have a good knowledge of the characteristics of atmospheric waves to better understand their role in the middle atmosphere dynamics and thermal structure.

A large spectrum of waves exists in the atmosphere. We consider here two main wave families, the planetary Rossby waves (PWs) and the gravity waves (GWs). They have 
very different characteristics and origins. PWs owe their existence to the equator to pole gradient of Coriolis force and are produced by the flow over orography and by contrasts in temperature between the land and ocean. Extratropical PWs can only propagate upwards in the middle atmosphere during the period of westerly winds (Charney and Drazin, 1961). In summer easterly winds prevail (Fig. 3) and PWs are blocked in the lower stratosphere. In winter PWs can propagate upwards at middle and high latitudes and can lead to dramatic deviations of the flow from its climatological mean, as for instance during Sudden Stratospheric Warmings (SSWs) (Matsuno, 1971; Labitzke, 1981; Charlton and Polvani, 2007; Butler et al., 2015; Maury et al., 2016). SSWs appear to be a strong issue for the evolution of the stratosphere and induced-tropospheric changes. Not only they affect the polar vortex where the ozone depletion takes place but they have also an impact on weather circulation at ground (Baldwin and Dunkerton, 2001; Cohen and Jones, 2011). PWs are explicitly represented in numerical weather forecast models. However their representation in the upper stratosphere and mesosphere lacks observations assimilated in the models at these altitudes.

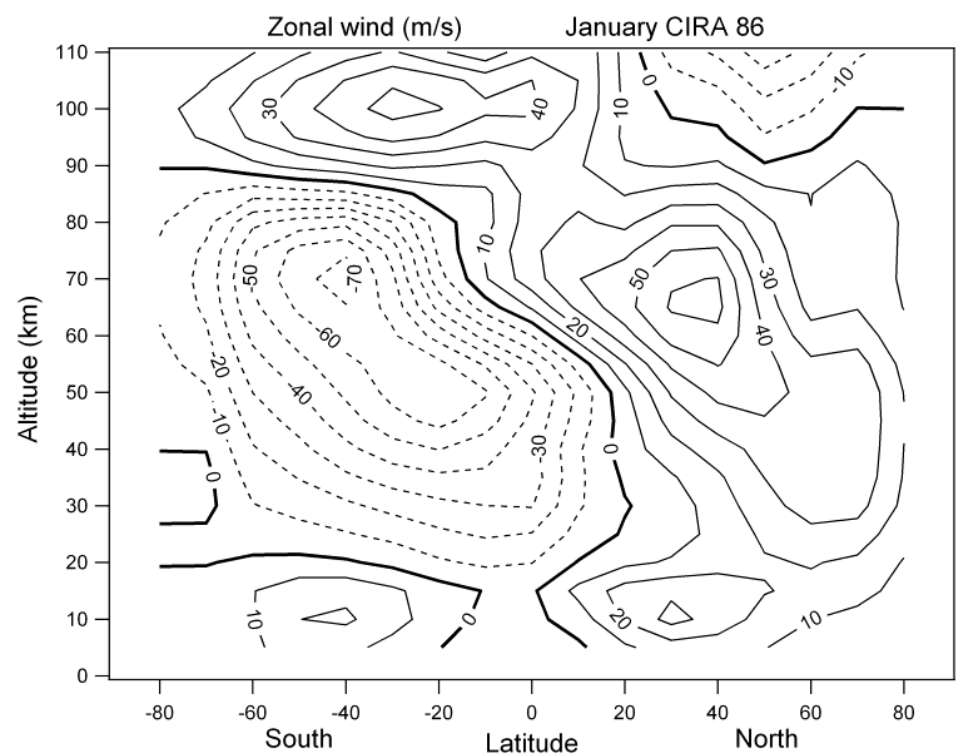

Fig. 3 Zonally averaged zonal wind ( $\left.\mathrm{ms}^{-1}\right)$ from the surface to $110 \mathrm{~km}$ altitude in January, based on CIRA 86 model (Fleming et al., 1988).

GWs are generated by the vertical displacement of air masses that creates a restoring gravity force in the opposite direction. The main sources of GWs are the orography, the cloud convection and the geostrophic adjustment of the jet stream. GWs propagate upwards in the stratosphere and the mesosphere depending on the vertical profile of horizontal wind until they break and they transfer their energy and momentum flux to the mean flow. GWs are sub-grid phenomena for most numerical weather forecast and climate models and they cannot be represented explicitly. It is then necessary to parameterize their effect on the general circulation. However very few data are available to adjust these parameterizations and high-resolution observations of GWs are strongly needed. Mesoscale models like WRF (Weather Research and Forecasting Model) can 
represent explicitly GWs and then build the bridge between observations and global models.

Time-resolved observations of the temperature profiles in the middle atmosphere are needed to validate the representation of atmospheric waves in the models. The Rayleigh lidar technique is well adapted to fulfil this role. Hauchecorne and Chanin (1980) initiated the measurement of stratospheric and mesospheric temperature using the Rayleigh Lidar technique 30 years ago at Haute-Provence Observatory (OHP). Monochromatic laser pulses are sent vertically into the atmosphere and a temporal analysis of the backscattered light provides information about the vertical structure and composition of the atmosphere. Above the top of the stratospheric aerosol layer (about $30 \mathrm{~km}$ ), Mie scattering by aerosols is negligible and the received signal, only due to Rayleigh scattering by air molecules, is directly proportional to the density of the atmosphere. The temperature profile is deduced from the density profile assuming that the density is in hydrostatic equilibrium and obeys the perfect gas law. The top altitude of the profile is limited upwards to 80 to $90 \mathrm{~km}$ by the signal to noise ratio depending on the power of the lidar system.

Rayleigh lidars, belonging to the Network for the Detection of Atmospheric Composition Changes (NDACC), are well adapted to the study of PWs (Hauchecorne and Chanin, 1983), SSWs (Angot et al., 2012), GWs (Wilson et al., 1990) in the upper stratosphere and in the mesosphere, as well as their interactions with the mean flow to induce mesospheric temperature inversions (Hauchecorne et al., 1987). The OHP Rayleigh lidar database is the longest temperature series and allowed one of the first detection of the cooling of the upper stratosphere and mesosphere (Hauchecorne et al., 1991; Keckhut et al., 1995; Ramaswamy et al., 2001). Now it is a key instrument to insure inter-satellite adjustment like AMSU series (Keckhut et al., 2015; Funatsu et al., 2016). One of the most powerful NDACC Rayleigh lidars is located at OHP and is operated in routine typically 45 hours per night with clear sky since 1979 (Keckhut et al., 1993). These observations allow studying the evolution of density and temperature profiles during the night. Vertical structures in these profiles reveal the presence of GWs that are usually generated in the troposphere and propagate upwards in the stratosphere and in the mesosphere. When they reach critical amplitude, they break and they transfer their momentum flux and energy to the mean flow. Rayleigh lidar observations have been extensively used for the study of gravity waves in the stratosphere and in the mesosphere. Wilson et al. (1990; 1991a; 1991b) analysed the characteristics and built the climatology of gravity waves above OHP. Hauchecorne et al. (1994) established the link between the gravity wave activity and prevailing winds during the DYANA campaign. Following these studies, Rayleigh lidar data have been extensively analysed for GW studies at low-latitude (Chane-Ming et al., 2000; Sivakumar et al. 2006; Li et al., 2010; Mzé et al., 2014), mid-latitudes (Rauthe et al., 2006; 2008; Sica and Argall, 2007) and high latitudes (Whiteway et al., 1997; Duck et al., 2001; Yamashita et al., 2009; Alexander et al., 2010). We present in this chapter recent results on atmospheric dynamics obtained from the analysis of Rayleigh lidar data at OHP. In the second section we present a new climatology of GWs obtained from 16 year of Rayleigh lidar data at OHP. We show also that, in the middle stratosphere, it is possible to obtain consistent results on GWs energy between GPS radio-occultation and lidar observations. In the third section we demonstrate that it is necessary to take into account possible changes in PW activity and SSW occurrence for the evaluation of temperature trends in the middle atmosphere. 


\section{Gravity waves}

\subsection{Gravity wave characterization from NDACC Rayleigh lidar data at Haute- Provence Observatory}

As presented in the introduction, Rayleigh lidars produce accurate observations with high temporal and vertical resolution, well adapted for studying atmospheric GWs. Rayleigh lidars provide vertical profiles of the total density of the atmosphere from about 30 to $90 \mathrm{~km}$ depending on the signal-to-noise ratio, and are powerful tools for studying atmospheric perturbations. Lidar measurements are performed continuously at OHP since late 1979 (in the beginning, the vertical resolution was $0.3 \mathrm{~km}$, and it has been improved to $0.075 \mathrm{~km}$ since 1994.

Another powerful Rayleigh lidar has been set-up recently at Maido Observatory. This new high-altitude atmospheric Observatory is located in the Western part of Reunion Island $\left(21^{\circ} \mathrm{S}\right.$, $55^{\circ} \mathrm{E}$ ) and benefits from very favourable weather conditions for lidar observations. The operations began in 2013 (Keckhut et al., 2015). Fig. 4 shows a series of temperature profiles reaching above $80 \mathrm{~km}$ in only 15 minutes of integration, which illustrates the potential of the lidar for GW studies. The propagation of wavy structures due to GWs is clearly visible, especially in the stratosphere. The temperature anomaly (deviation from the nightly mean profile) allows following the downward propagation of long period GWs during the 8 hours of observations (Fig. 5). This downward propagation of the wave phase is expected for GWs generated in the troposphere, the vertical direction of propagation of the wave phase being in opposite to the direction of propagation of the wave energy (Wilson et al., 1990).

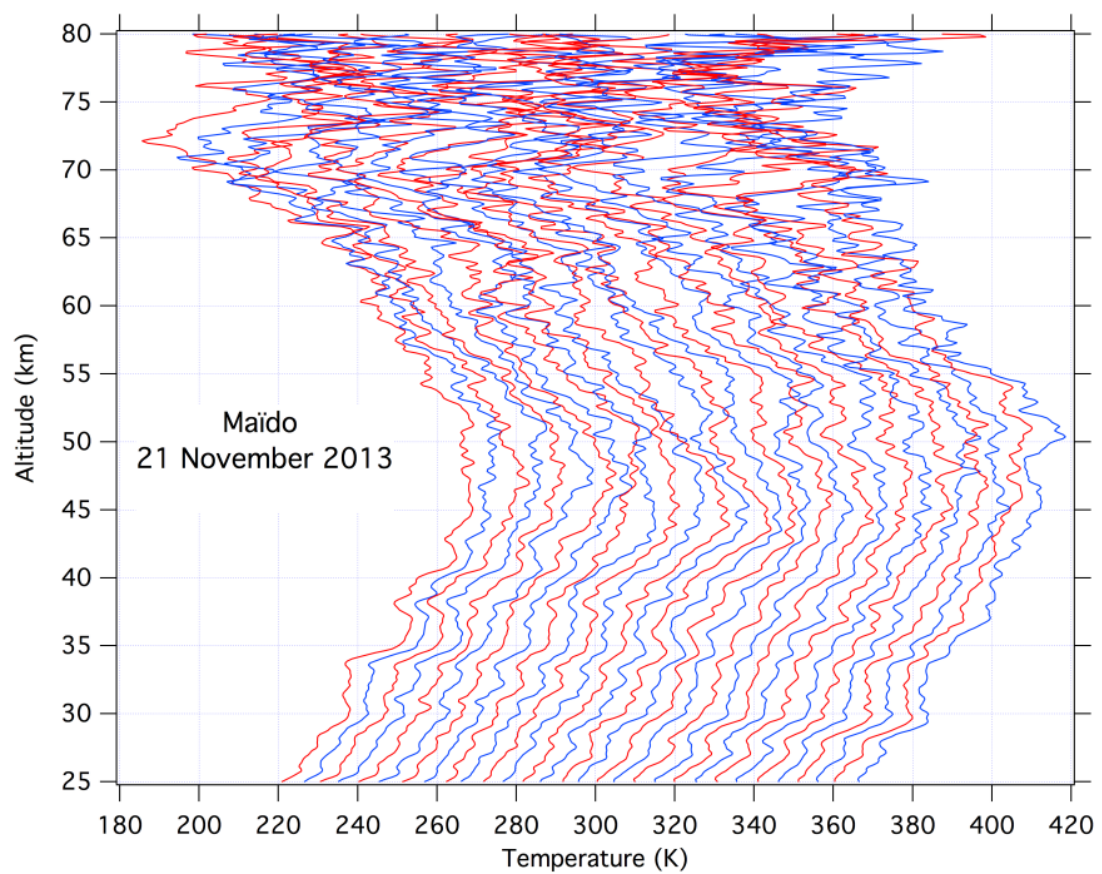

Fig. 4 Consecutive lidar temperature profiles at Maïdo Observatory on 21 November 2013. Each profile is integrated during 15 minutes. A $5 \mathrm{~K}$ shift is applied between two consecutive profiles for visibility. 


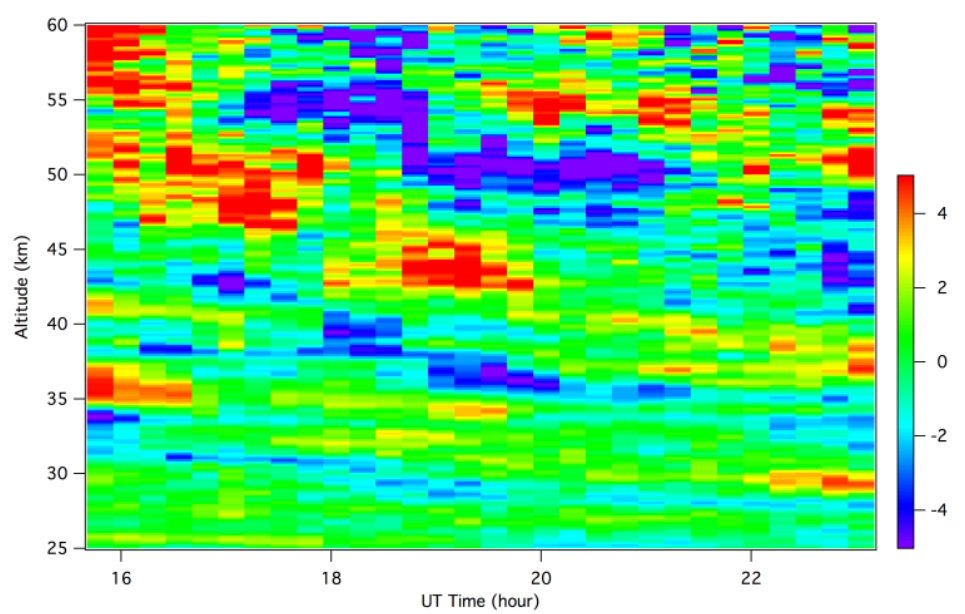

Fig. 5 Evolution of the temperature anomaly as seen by the lidar at Maïdo Observatory on 21 November 2013. Units are in K. The time resolution is 15 minutes.

GW activity, in terms of potential energy $\left(E_{p}\right)$, is estimated by analysing raw lidar signals with a variance method at OHP (Hauchecorne et al., 1994; Mzé et al., 2014).

We used the potential energy per unit mass, $E_{p}\left(\right.$ in $\mathrm{J}_{\mathrm{kg}}{ }^{-1}$ ), in order to characterize gravity wave activity, given by:

$$
E_{p}=\frac{1}{2}\left(\frac{g}{N}\right)^{2} V_{a t m}
$$

where $g$ is the gravitational acceleration $\left(\sim 9.8 \mathrm{~m} \cdot \mathrm{s}^{-2}\right), N$ the Brunt-Väisälä frequency and $V_{\text {atm }}$ the atmospheric variance.

Fig. 6 displays contour plots of the GW Ep climatology in 30-50 km and 50-85 km altitude ranges, as computed from night-time lidar measurements during 1996-2012. The variance is estimated using a vertical broadband filter centred around $3.5 \mathrm{~km}$ in the lower region and $7 \mathrm{~km}$ in the upper region to take into account the increase of dominant wavelengths from the stratosphere to the mesosphere. We found an annual cycle with maxima of GW activity occurring in winter and minimum in summer in the upperstratosphere and the lower mesosphere. We also found a semi-annual cycle with a maximum of GW activity occurring in winter and in summer and a minima during the equinoxes in the upper mesosphere/lower thermosphere. For more information see Mzé et al. (2014).

Seasonal averages of GW $E_{p}$ based on lidar observations over the 16-year time period are illustrated in Fig. 7. The $E_{p}$ increases with height but at a lower rate than the growth without dissipation indicated by the dashed black line. In order to better visualize the layers where GW dissipate, Fig. 8 shows the profile of GW potential energy expressed in $\mathrm{J} . \mathrm{m}^{-3}$ instead of $\mathrm{J} \cdot \mathrm{kg}^{-1}$ in the previous figures. With this unit an upward propagation without dissipation, and with the assumption that the wave frequency is not changing, corresponds to a vertical line. We observe dissipation at all altitudes and seasons except between 55 and $75 \mathrm{~km}$ in summer. The two main regions of wave dissipation are in the upper stratosphere between 30 and $50 \mathrm{~km}$ and in the upper mesosphere above $70 \mathrm{~km}$ in 
winter and above $75 \mathrm{~km}$ in summer.
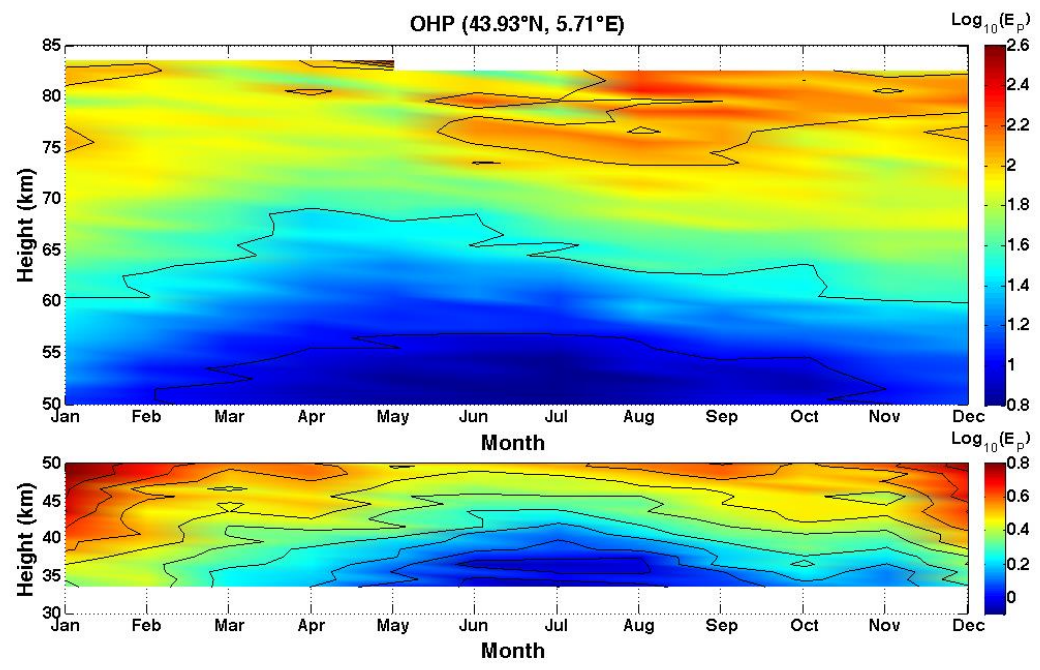

Fig. 6 Contour plots of the gravity wave $E_{p}$ climatology (in J.Kg-1) from lidar observations. $E_{p}$ is colored in a logarithmic scale $(\log 10)$ in $30-50 \mathrm{~km}$ and $50-85 \mathrm{~km}$ altitude ranges. The contours are separated by $0.2 \mathrm{~J} . \mathrm{Kg}^{-1}$. Adapted from Mzé et al., 2014.
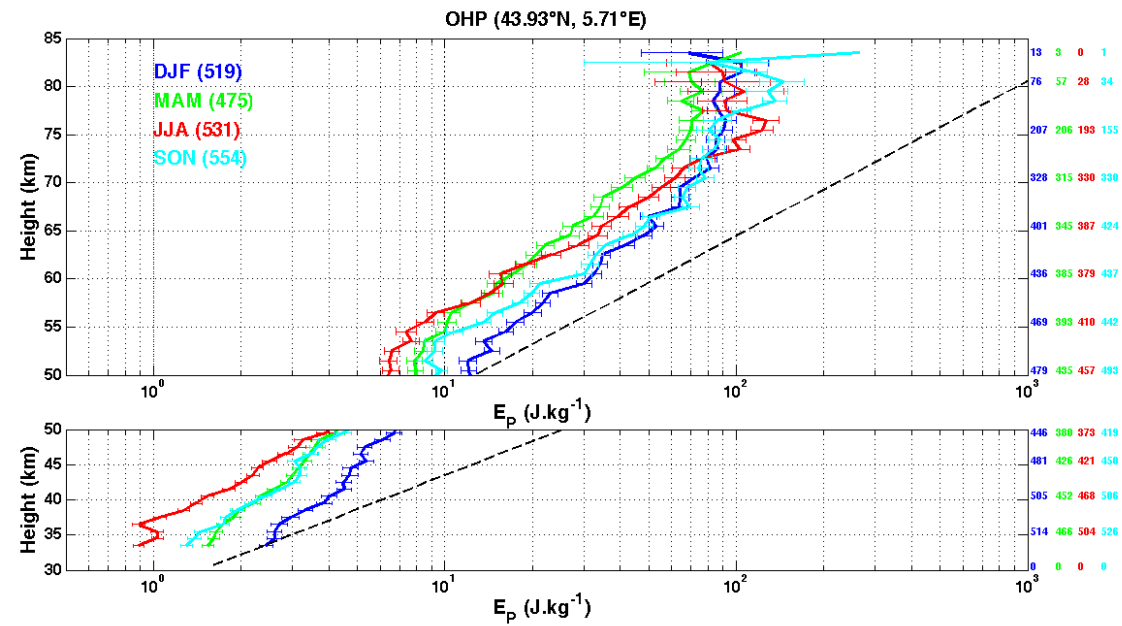

Fig. 7 Vertical profiles of $E_{\mathrm{p}}$ per unit mass (in J. $\mathrm{Kg}^{-1}$ ) in the upper-stratosphere and the mesosphere averaged over winter (DJF, blue line), spring (MAM, green line), summer (JJA, red line) and autumn (SON, cyan line). The conservative growth curve is also superimposed (black dashed line) with a constant density scale height $\mathrm{H}^{\sim} \mathrm{km}$. The numbers on the right part of the figure indicate the number of nights averaged per season for each altitude. Adapted from Mzé et al. (2014). 

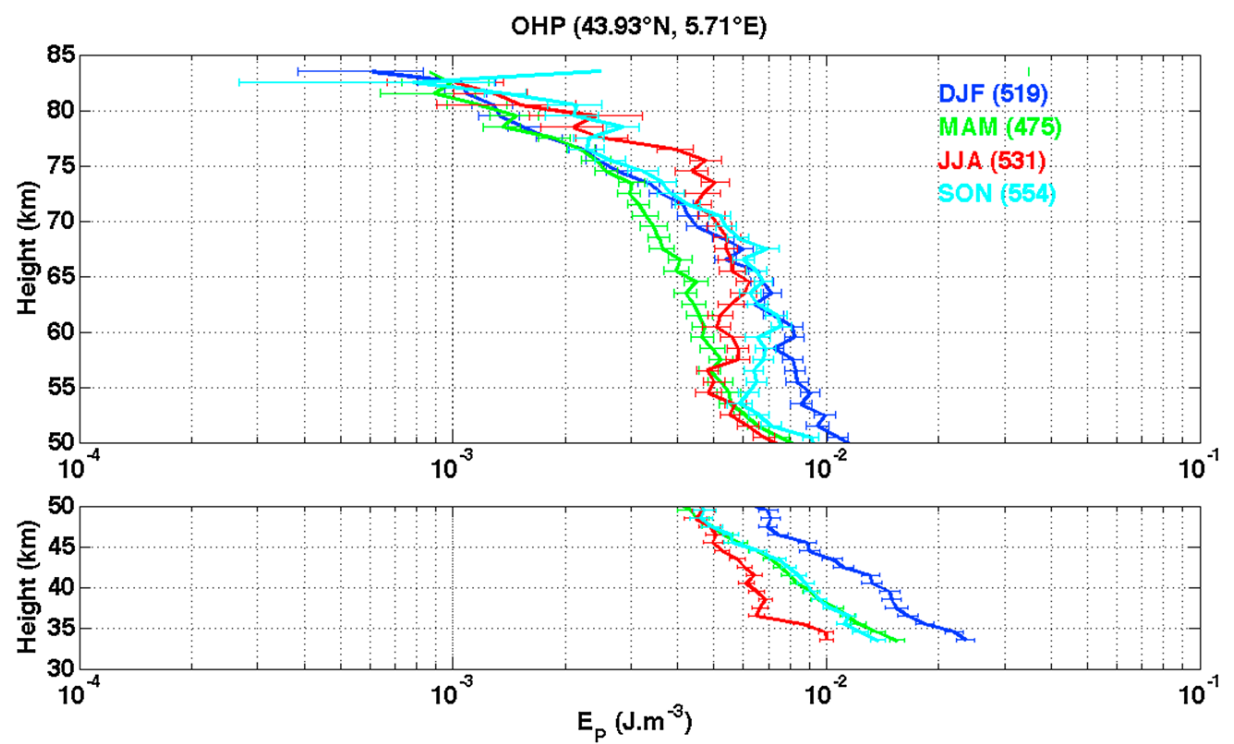

Fig. 8 The same as Fig. 7 except for the vertical profiles of potential energy per unit volume (in $\mathrm{Jm}^{-3}$ ). Adapted from Mzé et al. (2014).

\subsection{Evaluation of gravity wave potential energy combining GPS radio occultations and Rayleigh lidar data}

Global Positioning System radio occultation (GPS-RO) temperature profiling technique, featuring high vertical resolution and global coverage (Kursinsky et al., 1997; Haij et al., 2002; Wickert et al., 2004), represents a powerful tool for climate and trend studies in the upper troposphere-lower stratosphere (Randel et al., 2009; Steiner, 2013) and for studying the sources and climatology of gravity waves (Belloul et al., 1997; Faber et al., 2013). Operational since April 2006 until present, COSMIC GPS-RO system, consisting of 6 low Earth-orbiting micro-satellites, provides 1500-2000 occultations per day with sampling density maximizing at mid-latitudes, about $1-2$ profiles per day in a $5^{\circ} \times 5^{\circ}$ bin at OHP latitude (Anthes et al., 2008). GPS-RO temperature observations cover the altitude range between about 8 and $35 \mathrm{~km}$, with the highest accuracy $(<0.5 \mathrm{~K})$ in the lower stratosphere and a vertical resolution of $0.2-1.4 \mathrm{~km}$.

Shown in Fig. 9 is a time series of GW potential energy $\left(E_{p}\right)$ retrieved through analysis of temperature perturbations (Khaykin et al., 2015). The potential energy of GW has been evaluated from the fluctuations in vertical temperature profiles using 2 different techniques, GPS-RO from 10 to $35 \mathrm{~km}$ and Rayleigh lidar above $33.5 \mathrm{~km}$. This allows reconstructing the time evolution of GW $E_{p}$ from the 10 to $50 \mathrm{~km}$ (Fig. 9). In the overlapping altitude range between 33.5 and $35 \mathrm{~km}$ we observe a good agreement between the two techniques (not shown). The time of enhancement of GW $E_{p}$ estimated from MERRA meteorological reanalysis (contour lines) is also in good agreement with the observations, but the energy is about 5 times lower in the reanalysis because the model can only capture one part of the GW spectrum. A strong increase of GW $E_{p}$ is observed at the beginning of January above $35 \mathrm{~km}$. This enhancement is related to the strong dynamical perturbation due to the occurrence of a SSW (Le Pichon et al., 2015). This event was reflected in the lidar temperature profile on 10 January 2013 (Fig. 10 
left) with an enhancement and a descent of the stratopause and a strong positive temperature gradient between 35 and $40 \mathrm{~km}$, corresponding to a very stable atmospheric layer favouring the increase of GW amplitude (Hauchecorne et al., 1987).

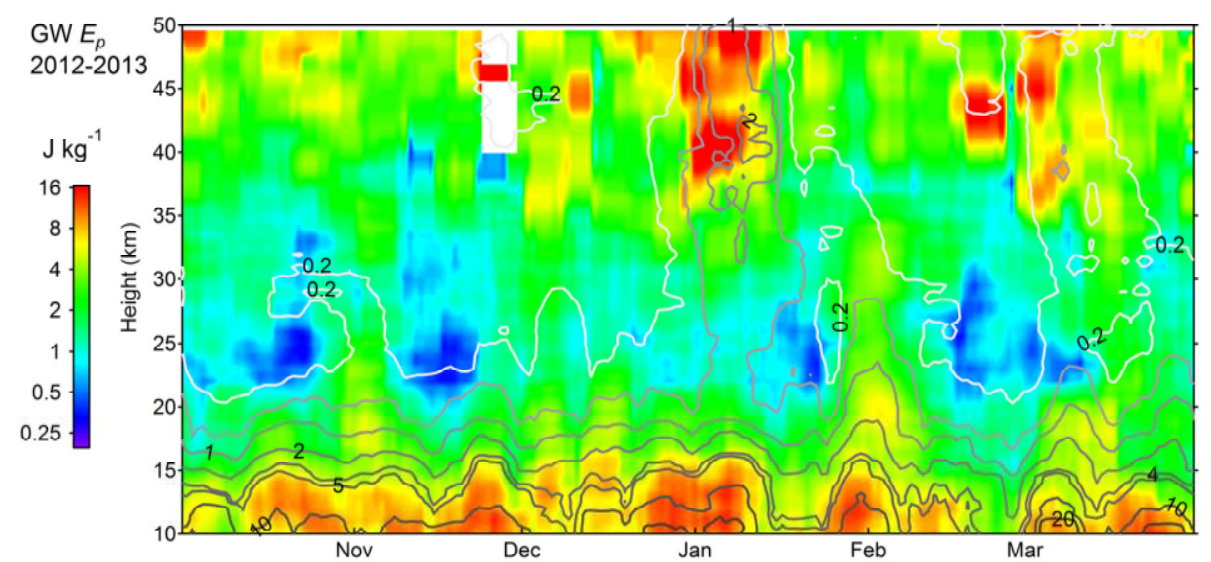

Fig. 9 Evolution of GW $E_{p}$ at OHP from combined GPS-RO and Rayleigh lidar data during winter 2012-2013. Adapted from Khaykin et al. (2015). Contour lines show the GW $E_{p}$ computed frm MERRA meteorological reanalysis.
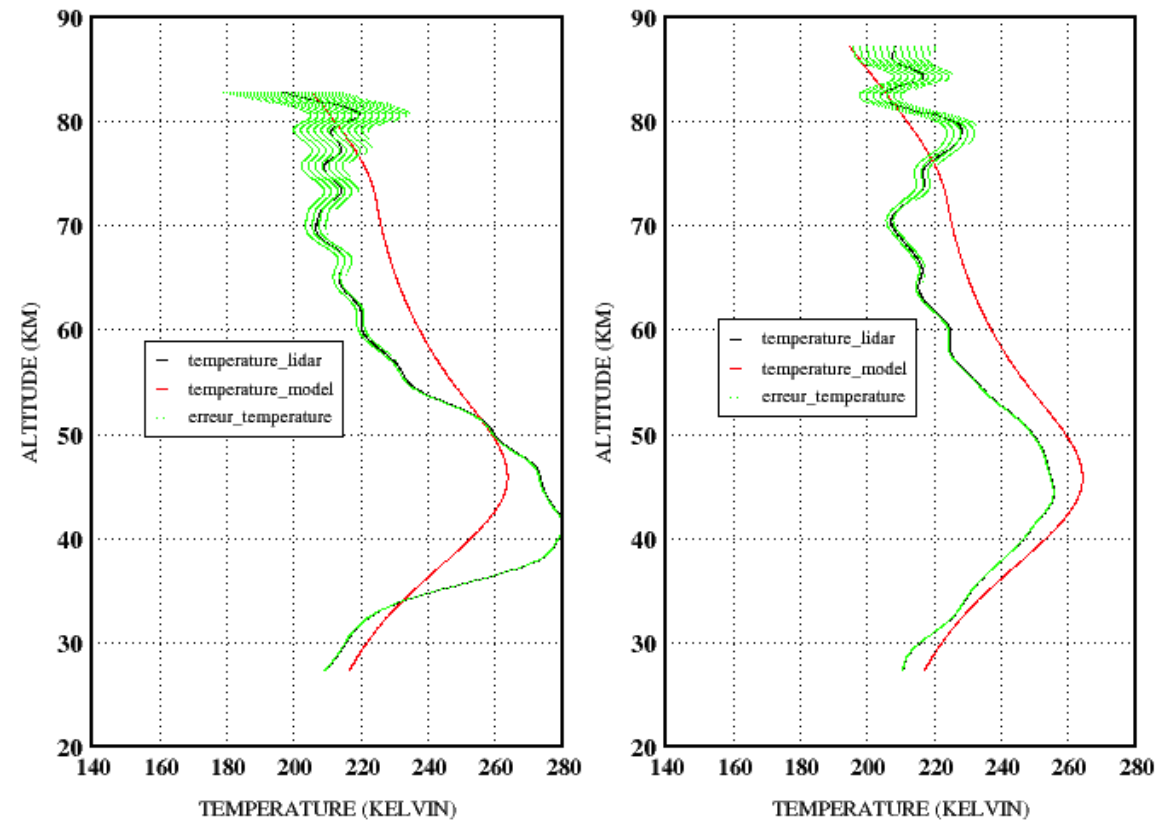

Fig. 10 Nightly mean Rayleigh lidar profiles at OHP (left side) on 10 January 2013 during a major stratospheric warming and (right side) one week later on 17 January 2013 with a cold middle atmosphere. The green shaded area indicates uncertainty $(-/+1$ sigma $)$ and the black line represents the NRLMSISE-00 empirical model (Picone et al., 2003). 


\section{Large scale dynamics and impact on temperature climatology and trend}

As mentioned in the introduction, the upward propagation of extratropical PWs is only possible during the period of westerly zonal wind from October to April. These waves create perturbations in the vertical profile of temperature with typical periods ranging from 1 week to 1 month. These perturbations are captured by the OHP Rayleigh lidar during each winter season (Fig. 11), allowing studying their characteristics (Hauchecorne et al., 2006). The propagation of PWs depends on the meridional-vertical structure of zonal wind and temperature fields. It is then sensitive to one of the major dynamical phenomena, the Quasi Biennial Oscillation (QBO). The QBO is a quasi-periodic oscillation of the equatorial zonal wind with a 28-month average period (Fig 12). The downward propagation of the QBO wind is due to the interaction of the zonal wind with GWs and equatorial PWs propagating in both directions and accelerating the mean flow in their direction of propagation when they break (see Baldwin et al., 2011 for a review paper on QBO). The interaction between GWs and the QBO zonal wind is illustrated by FiG. 12 showing the enhancement of GW $E_{p}$ in the equatorial band along the zero wind line.

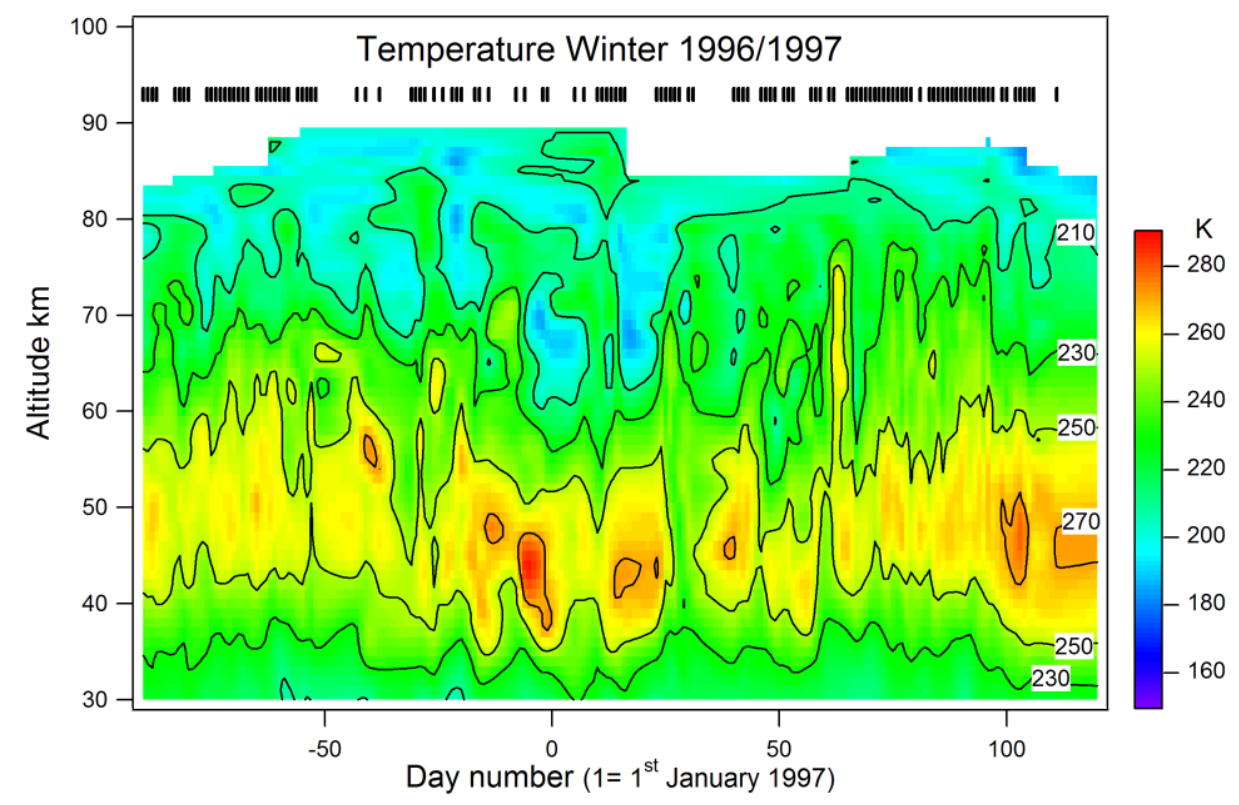

Fig. 11 Evolution of the temperature at OHP during winter 1996-1997. Days with measurements are indicated with a vertical bar at the top of the figure. Adapted from Hauchecorne et al. (2006). 


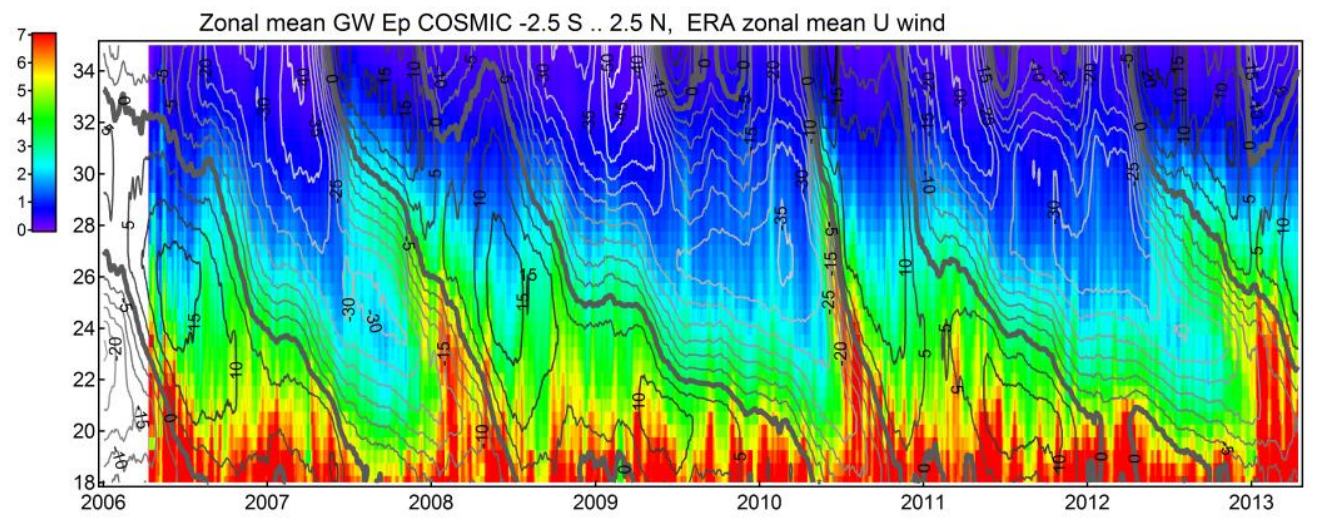

Fig. 12 Contour lines represent the time-pressure section of the equatorial zonal wind updated from Naujokat (1986), showing the downward propagation of the QBO zonal wind from 2006 to 2013. Easterly wind contours (negative values) are plotted with grey lines and Westerly winds (positive values) with black lines. Colour filling represents the GW $E_{p}$ in J.kg-1 in the latitude band $2.5^{\circ} \mathrm{S}-2.5^{\circ} \mathrm{N}$, estimated using GPS-RO data.

\begin{tabular}{|c|c|c|c|c|c|}
\hline Year & Wind m/s & QBO sign & Year & Wind m/s & QBO sign \\
\hline 1982 & -14 & E & 1992 & -16.5 & E \\
\hline 1983 & 15 & W & 1993 & 12.5 & W \\
\hline 1984 & -8 & E & 1994 & -1.5 & E \\
\hline 1985 & -12 & E & 1995 & 5.5 & W \\
\hline 1986 & 15 & W & 1996 & 3.5 & W \\
\hline 1987 & -9 & E & 1997 & -24 & E \\
\hline 1988 & 9 & W & 1998 & 12.5 & W \\
\hline 1989 & 12 & W & 1999 & -14 & E \\
\hline 1990 & -26 & E & 2000 & 12 & W \\
\hline 1991 & 11.5 & W & 2001 & -7 & E \\
\hline
\end{tabular}

Table 1 Amplitude of equatorial wind in January-February at $40 \mathrm{hPa}$. QBO data series from Stratospheric Research Group, Freie Universität Berlin, are available at http://www.geo.fuberlin.de/en/met/ag/strat/produkte/qbo/index.html. Updated from Naujokat et al. (1986).

Free planetary Rossby waves have a westward propagation with preferential periods depending on their zonal wave number and their mode (Kasahara, 1980). In the Northern winter stratosphere the two dominant modes are the so-called 16-day wave with zonal number 1 (one maximum and one minimum along a latitude circle) and the 12-day wave with zonal wave number 2 . In order to detect the spectral distribution of PWs observed with the OHP lidar, a spectral analysis of temperature anomalies (deviations from the climatology) is performed at all altitudes for all winters from 1982 to 2001. Integrated nightly-mean lidar data interpolated in time using cubic spline functions (Hauchecorne et al., 1991) are used. Energy spectra are averaged over winters 
with QBO West phase and winters with QBO East phase and are represented on Fig. 13. The QBO sign is defined according to the zonal wind at $40 \mathrm{hPa}$ in January-February (Table 1).

For both QBO phases we observe two regions of enhanced PW energy, in the upper stratosphere around $40 \mathrm{~km}$ and in middle the mesosphere above $65 \mathrm{~km}$. The lower one is clearly associated with PWs and is limited to frequencies lower than 0.1 day $^{-1}$ (periods longer than 10 days). The upper one extends to higher frequencies and has been attributed by Hauchecorne et al. (1991) to a combination of PWs and the effect of GW breaking on the mean temperature. For QBO West (Fig. 13, top) two maxima appear at $40 \mathrm{~km}$ around 0.050-0.055 day-1 (18-20 days) and 0.075 day ${ }^{-1}$ (13 days). These two peaks are tentatively attributed to the two dominant 12 -day and 16-day Rossby waves.

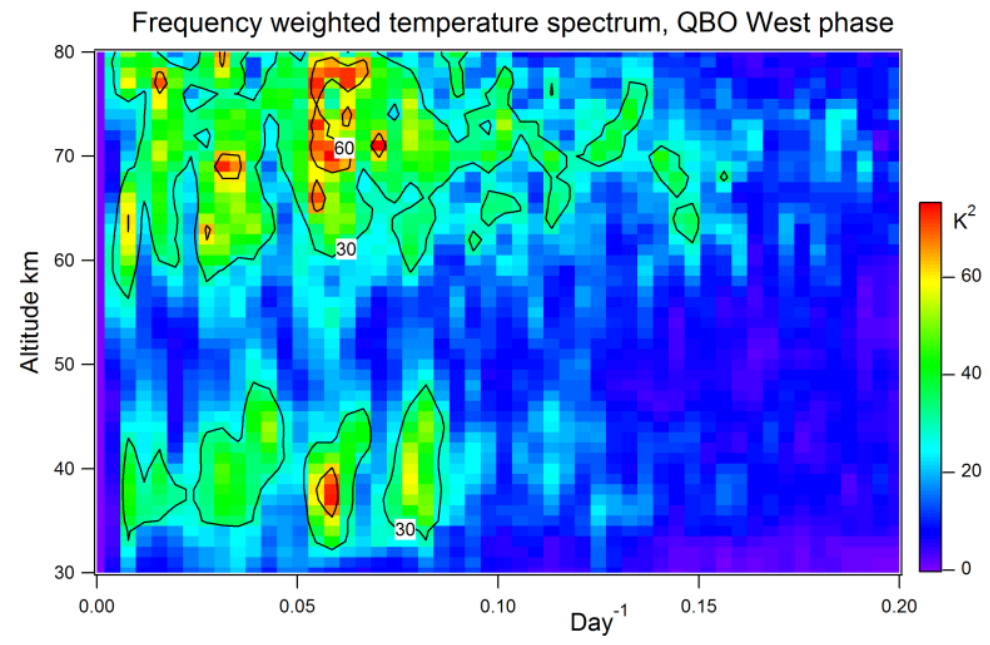

Frequency weighted temperature spectrum, QBO East phase

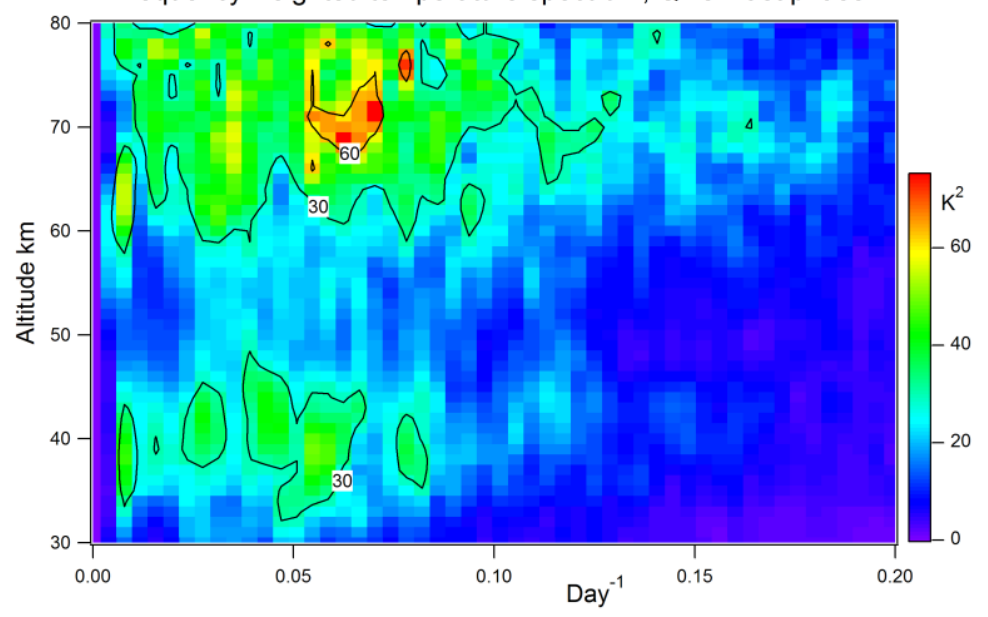

Fig. 13 Energy spectrum of temperature perturbations averaged over winters in QBO West phase (top) and in QBO East phase (bottom). The power spectral density is multiplied by the frequency to have a better visualisation of energy maxima due to dominant PW modes. Consequently the unit is $\mathrm{K}^{2}$.day ${ }^{-1} / \mathrm{day}^{-1}=\mathrm{K}^{2}$. Adapted from Hauchecorne et al. (2006). 
The shift towards longer periods compared to theoretical values may be explained by the Doppler shift due to the wave propagation in westerly winds (Hauchecorne et al., 2006). For QBO East the two peaks are also visible but with a smaller amplitude. This seems to indicate that the propagation of planetary Rossby waves is favoured in the QBO West phase. The interpretation of the results in the mesosphere is more difficult due to a combination of PW and GW effects but the enhanced PW energy around 18-20 days is observed for both QBO phases. The variability of the temperature may also be affected by thermal tides in the mesosphere. However we do not expect a significant impact in our results because lidar observations are usually made in the first part half of the night with little change in local time;

The temperature of the middle atmospheric temperature is not only driven by radiative processes, but also by wave-mean flow interactions, unambiguously noticeable in Northern winter through large events like SSWs. This makes the interpretation of observed trends more complex. Angot et al. (2012) described a new method to separate the contribution of radiative and dynamics processes in observed temperature trends. In this new method the strong influence of SSWs in temperature trend evaluation is identified and removed to provide a "background" temperature trend estimate, in better agreement with what is expected from direct radiative effects induced by atmospheric composition changes. The data set used results from OHP Rayleigh lidar measurements from 1979 to 2009 and combined with daily-collocated radiosonde profiles. Fig. 14 presents the histogram of temperature anomalies (deviations from the seasonal evolution) at $40 \mathrm{~km}$ for two half-month periods. In the first half of May (left part), the distribution is narrow and mono-modal, showing no clear effect of the dynamics on the temperature. Conversely, the distribution is much broader and clearly bi-modal in the first half of February, with the larger and colder Gaussian curve attributed to background conditions, weakly affected by PW activity, and the smaller and warmer Gaussian curve attributed to perturbed conditions with enhanced PW activity and occurrence of a SSW.
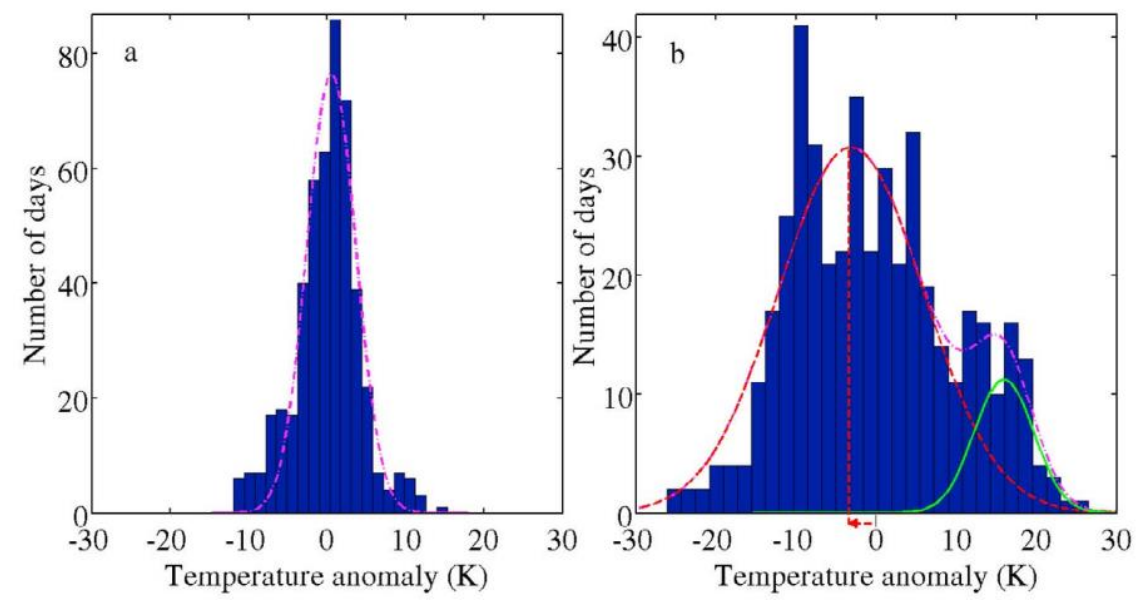

Fig. 14 Histogram of temperature anomalies from the seasonal evolution (left) during the second half of May and (right) during the first half of February for the period 1979-2009. The histogram is fitted with a double Gaussian curve to separate the background (red dashed line) and the dynamically perturbed (green solid line) conditions. The red arrows highlights the mean temperature anomaly $(-3.2 \mathrm{~K})$ in background conditions. Adapted from Angot et al. (2012). 
winter. Temperature trends are then calculated using the derived background anomalies and compared to the estimation using all data (Fig.15). With this new methodology the long-term trend during winter showed a larger cooling at all altitudes from 30 and $80 \mathrm{~km}(-2 \mathrm{~K} /$ decade at $40 \mathrm{~km})$ than when all data are used $(-0.4 \mathrm{~K} /$ decade at $40 \mathrm{~km}$ ). The cooling of the winter background temperature is then closer to the summer trend estimate, not perturbed by the dynamical activity. Temperature warmings associated with dynamical disturbances like SSWs (not shown) experienced an increase both in their intensity and occurrence that led to partly cancel out the longterm cooling due to radiative processes. A possible explanation of this evolution is the acceleration of the Brewer-Dobson circulation predicted by Chemistry-Climate Models (Butchart, 2014). A better characterization of SSW events (Maury et al., 2016) could help to improve our understanding of the role of these events in the long-term evolution of the temperature in the middle atmosphere.

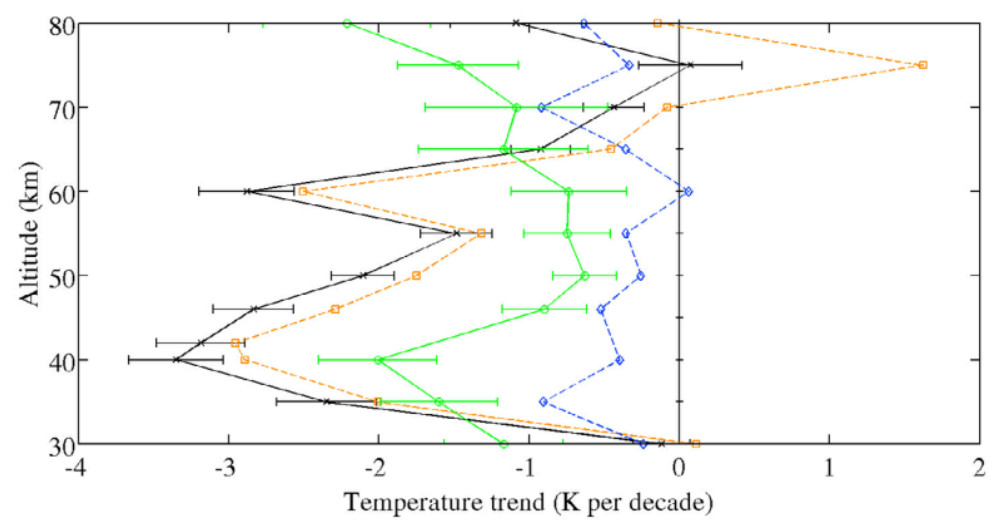

Fig. 15 Linear temperature trend during the period 1979-2009 at $40 \mathrm{~km}$ using all summer data (orange dashed line and squares), summer background data (black line and crosses), all winter data (blue dashed line and diamonds) and winter background data (green lines and circles). One-sigma uncertainties are indicated for summer and winter background conditions. Adapted from Angot et al. (2012).

\section{Conclusion}

The middle atmosphere is a region very sensitive not only to changes in the radiative budget of the whole atmosphere but also to its dynamical response to these changes at different space and time scales. The already observed cooling of the middle atmosphere due to the increase of greenhouse gases is expected to continue. However the rate of cooling will strongly depend on the evolution of complex interactions between dynamical, radiative and photochemical processes. Observations are then highly needed to improve our understanding of the role of the dynamics in the past and future evolution of the middle atmosphere. Rayleigh lidars providing time-resolved accurate temperature profiles from the middle stratosphere to the top of mesosphere are very efficient tools to study the characteristics of GWs and PWs and their impact on the mean temperature field. Together with other types of instruments set-up in the frame of the European Design Study projects ARISE and ARISE2, Doppler wind lidars, MesosphereStratosphere-Troposphere (MST) and meteor radars, the IMS (International Monitoring System) infrasound network, airglow imagers and ionospheric sounders, they will 
contribute to a better knowledge and a better representation of middle atmospheric processes in numerical weather prediction and climate models.

\section{Acknowledgments}

This work was partly supported by ARISE (FP7) and ARISE2 (H2020) design study projects, funded by the European Union and by Stradyvarius project funded by the Agence Nationale de la Recherche, France.

\section{References}

Alexander M.J., Geller M., McLandress C., Polavarapu S., Preusse P., Sassi F., Sato K., Eckermann S., Ern M., Hertzog A., Kawatani Y.A., Pulido M., Shaw T., Sigmond M., Vincent R., Watanabe S. (2010), Recent developments in gravity-wave effects in climate models and the global distribution of gravity-wave momentum flux from observations and models. Q. J. R. Meteorol. Soc. 136:1103-1124. doi: 10.1002/qj.637

Andrews D., Taylor F., McIntyre M. (1987), The Influence of Atmospheric Waves on the General Circulation of the Middle Atmosphere [and Discussion]. Philosophical Transactions of the Royal Society of London. Series A, Mathematical and Physical Sciences, 323(1575): 693-705. Retrieved from http://www.jstor.org/stable/38143

Angot, G., Keckhut P., Hauchecorne A., Claud C. (2012), Contribution of stratospheric warmings to temperature trends in the middle atmosphere from the lidar series obtained at Haute-Provence Observatory (44 degrees N), J. Geophys. Res., 117: D21102. doi: 10.1029/2012JD017631

Anthes R.A., Bernhardt P.A., Chen Y., Cucurull L., Dymond K.F., Ector D., Healy S.B., Ho S.P., Hunt D.C., Kuo Y.H., Liu H., K. Manning K., McCormick C., Meethan T.K., Randel W.J., Rocken C., Schreiner W.S., Sokolovskiy S.V., Syndergaard S., Thompson D.C., Trenberth K.E., Wee T.K., Yen N.L., Zeng Z. (2008), The COSMIC/FORMOSAT-3 Mission Early Results, Bull. Amer. Met. Soc.,89(3): 313-333. doi:10.1175/BAMS-89-3313doi:10.1175/BAMS-89-3-313

Baldwin, M.P., Gray, L. J., Dunkerton, T. J., Hamilton, K., Haynes, P. H., Randel, W. J., Holton, J. R., Alexander, M. J., Hirota, I., Horinouchi, T., Jones, D. B. A., Kinnersley, J. S., Marquardt, C., Sato, K., Takahashi, M. (2001), The Quasi-Biennial Oscillation, Rev. Geophys., 39: 179-229.

Belloul B., Hauchecorne A. (1997), Horizontal homogeneities in occultation methods: the case of atmospheric gravity waves, Radio Sci., 32: 469-478.

Butchart N. (2014), The Brewer-Dobson circulation, Rev. Geophys., 52: 157-184, doi:10.1002/2013RG000448

Butler A.H., Seidel D.J., Hardiman S.C., Butchart N., Birner T., Match A. (2015), Defining Sudden Stratospheric Warmings, Bull. Am. Meteorol. Soc., 96: 1913-1928.

Chane Ming F., Molinaro F., Leveau J., Keckhut P., Hauchecorne A. (2000), Analysis of gravity waves in the tropical middle atmosphere with lidar using wavelet techniques, Annales Geophysicae, 18: 485-498. 
Charlton, A. J., Polvani L.M. (2007), A new look at stratospheric sudden warmings. Part I: Climatology and modeling benchmarks, J. Clim., 20(3): 449-469, doi:10.1175/JCLI3996.1

Charney J. G., Drazin P.G. (1961) Propagation of planetary scale disturbances from the lower into the upper atmosphere, J. Geophys. Res., 66: 83-109.

Cohen J., Jones J. (2011), Tropospheric precursors and stratospheric warmings, J. Clim., 24: 6562-6572, doi:10.1175/2011JCLI4160.1

Duck T. J., Whiteway J.A., Carswell A.I. (2001), The gravity wave-arctic stratospheric vortex interaction, J. Atmos. Sci., 58(23): 3581-3596. doi:10.1175/15200469(2001)058<3581:TGWASV>2.0.CO;2

Faber A., Llamedo P., Schmidt T., de la Torre A., Wickert J. (2013), On the determination of gravity wave momentum flux from GPS radio occultation data, Atmos. Meas. Tech., 6: 3169-3180. doi:10.5194/amt-6-3169-2013.

Fleming E.L., Chandra S., Schoeberl M.R., Barnett J.J. (1988), Monthly mean global climatology of temperature, wind, geopotential height, and pressure for 0-120 km. NASA Tech Memo 100697.

Fritts D. C., Alexander M.J. (2003), Gravity wave dynamics and effects in the middle atmosphere, Rev. Geophys., 41: 1003. doi:10.1029/2001RG000106

Funatsu B., Claud C., Keckhu P., Hauchecorne A., Leblanc T. (2016) Regional and seasonal stratospheric temperature trends in the last decade (2002-2014) from AMSU observations. J. Geophys. Res., 121 (14): 8172-8185.

Hajj G. A., Kursinski E.R., Romans L.J., Bertiger W.I., Leroy, S.S. (2002), A technical description of atmospheric sounding by GPS occultation, J. Atmos. Sol.-Terr. Phys., 64: 451-469. doi:10.1016/S1364-6826(01)00114-6, 2002

Hauchecorne A., Chanin M.L. (1980), Density and temperature profiles obtained by lidar between 30 and $70 \mathrm{~km}$. Geophys Res Lett 7: 564-568.

Hauchecorne A., Chanin M.L. (1983), Mid-latitude observations of planetary waves in the middle atmosphere during the winter of 1981-1982, J Geophys Res 88: 3843-3849.

Hauchecorne A., Chanin M.L., Wilson R. (1987), Mesospheric temperature inversion and gravity wave breaking, Geophys. Res. Let., 14: 933-936.

Hauchecorne A., Chanin M.L. (1988), Planetary waves-mean flow interaction in the middle atmosphere: modelisation and comparison with lidar observations, Ann. Geophys., 6: 409-416.

Hauchecorne A., Chanin M.L., Keckhut P. (1991), Climatology and trends of the middle atmospheric temperature $(33-87 \mathrm{~km})$ as seen by Rayleigh lidar above south of France, J. Geophys. Res., 96: 15297-15309.

Hauchecorne A., Gonzalez N., Souprayen C., Manson A.H., Meek C.E., Singer W., Fahrytdinova A.N. , Hoppe U.P., Boska J., Lastovicka J., Scheer J., Reisin E.R., Graef H. (1994), Gravity wave activity and its relation with prevailing winds during DYANA, J. Atmos. Terr. Phys., 56: 1765-1778.

Hauchecorne A., Keckhut P., Chanin M.L. (2006), Interannual variability and long term changes in planetary wave activity in the middle atmosphere observed by lidar, Atmos. Chem. Phys. Discuss., 6 : 11299-11316. doi:10.5194/acpd-6-11299-2006 
Hauchecorne A., Keckhut P., Chanin M.L. (2009), Dynamics and transport in the middle atmosphere, Infrasound Monitoring for Atmospheric Studies, Springer, pp.665-683, Earth and Environmental .

Hauchecorne A., Bertaux J.L., Dalaudier F., Keckhut P., Lemennais P., Bekki S., Marchand M., Lebrun J. C., Kyrölä E., Tamminen J., Sofieva V., Fussen D., Vanhellemont F., Fanton d'Andon O., Barrot G., Blanot L., Fehr T., Saavedra de Miguel L. (2010), Response of tropical stratospheric 03, NO2 and NO3 to the equatorial Quasi-Biennial Oscillation and to temperature as seen from GOMOS/ENVISAT, Atmos. Chem. Phys., 10: 8873-8879.

Kasahara A. (1980), Effect of Zonal Flows on the Free Oscillations of a Barotropic Atmosphere, J. Atmos. Sci., 37: 917-929.

Khaykin S., Hauchecorne A., Mze N., Keckhut P (2015), Seasonal variation of gravity wave activity at midlatitudes from 7 years of COSMIC GPS and Rayleigh lidar temperature observations, Geophys. Res. Lett., 42 (4): 1251-1258.

Keckhut P., Hauchecorne A., Chanin M.L. (1993), A critical review of the data base acquired for the long term surveillance of the middle atmosphere by Rayleigh lidar. J Atm Ocean Tech 10: 850-867.

Keckhut P., Hauchecorne A., Chanin M.L. (1995), Mid-latitude long-term variability of the middle atmosphere: trends, cyclic and episodic changes, J. Geophys. Res., 100: 1888718897.

Keckhut P., Courcoux Y., Baray J.-L., Porteneuve J., Vérèmes H., Hauchecorne A., Dionisi D., Posny F., Cammas J.-P., Payen G., Gabarrot F. et al. (2015), Introduction to the Maïdo Lidar Calibration Campaign dedicated to the validation of upper air meteorological parameters, J. Appl. Remote Sens. 9 (1): 094099. doi: 10.1117/1.JRS.9.094099

Keckhut P., Funatsu B. M., Claud C., Hauchecorne A. (2015), Tidal effects on stratospheric temperature series derived from successive advanced microwave sounding units, Quarterly Journal of the Royal Meteorological Society, 141 (687): 477-483.

Kursinski E. R., Hajj G. A., Schofield J. T., Linfield R. P., Hardy K. R. (1997), Observing Earth's atmosphere with radio occultation measurements using the Global Positioning System, J. Geophys. Res., 102: 23429-23465. doi:10.1029/97JD01569

Labitzke K. (1981,), Stratospheric-mesospheric midwinter disturbances: A summary of observed characteristics, J. Geophys. Res., 86(C10): 9665-9678. doi:10.1029/JC086iC10p09665

Le Pichon A., Assink J. D., Heinrich P., Blanc E., Charlton-Perez A. J., Lee C.-F., Keckhut P., Hauchecorne A., Rüfenacht R., Kämpfer N., Drob D. et al. (2015), Comparison of colocated independent ground-based middle-atmospheric wind and temperature measurements with Numerical Weather Prediction models, J. Geophys. Res., 120 (16): 8318-8331.<10.1002/2015JD023273>

Li T., Leblanc T., McDermid I.S. , Wu D.L., Dou X., Wang S. (2010), Seasonal and interannual variability of gravity wave activity revealed by long-term lidar observations over Mauna Loa Observatory, Hawaii, J. Geophys. Res., 115: D13103. doi:10.1029/2009JD013586

Lindzen, R. S. (1981), Turbulence and stress owing to gravity wave and tidal breakdown, J. Geophys. Res., 86(C10), 9707-9714, doi:10.1029/

JC086iC10p09707. 
Matsuno T. (1971), A dynamical model of the stratospheric sudden warming, J. Atmos. Sci., 28: 1479-1494.

Maury P., Claud C., Manzini E., Hauchecorne A., Keckhut P. (2016), Characteristics of stratospheric warming events during Northern winter, J. Geophys. Res., 121: 53685380. doi:<10.1002/2015JD024226>

Mzé N., Hauchecorne A., Keckhut P., Thétis M. (2014), Vertical distribution of gravity wave potential energy from long-term Rayleigh lidar data at a northern middle-latitude site, J. Geoph. $\quad$ Res.: Atmospheres, 119 (21): 12069-12083. doi: $<10.1002 / 2014$ JD022035>

Naujokat B. (1986), An update of the observed quasi-biennial oscillation of the stratospheric winds over the tropics, J. Atmos. Sci., 43: 1873-1877

Picone J.M., Hedin A.E., Drob D.P., Aikin A.C. (2002), NRLMSISE-00 empirical model of the atmosphere: Statistical comparisons and scientific issues, J. Geophys. Res., 107(A12): 1468. doi:10.1029/2002JA009430

Ramaswamy V., et al. (2001), Stratospheric temperature trends: Observations and model simulations, Rev. Geophys., 39(1): 71-122. doi:10.1029/1999RG000065

Randel W. J., Shine K. P., Austin J., Barnett J., Claud C., Gillett N. P., Keckhut P., Langematz U., Lin R., Long C., Mears C., Miller A., Nash J., Seidel D.J., Thompson D.W. J., Wu F., Yoden, S. (2009), An update of observed stratospheric temperature trends, J. Geophys. Res., 114: D02107. doi:10.1029/2008JD010421

Rauthe M., Gerding M., Höffner J., Lübken F.J. (2006), Lidar temperature measurements of gravity waves over Ku"hlungsborn (54N) from 1 to $105 \mathrm{~km}$ : A winter-summer comparison, J. Geophys. Res., 111: D24108. doi:10.1029/2006JD007354

Rauthe M., Gerding M., Lübken F.J. (2008), Seasonal changes in gravity wave activity measured by lidars at mid-latitudes, Atmos. Chem. Phys., 8: 6775-6787. doi:10.5194/acp-8-6775-2008

Shepherd T.G. (2000), The middle atmosphere, J. Atmos. Sol.-Terr. Phys., 62: 1587-1601.

Sica R.J., Argall P.S. (2007), Seasonal and nightly variations of gravity-wave energy density in the middle atmosphere measured by the Purple Crow Lidar, Ann. Geophys., 25: 2139-2145. doi:10.5194/angeo-25-2139-2007

Sivakumar V., Rao P.B., Bencherif H. (2006), Lidar observations of middle atmospheric gravity wave activity over a low-latitude site (Gadanki, $13.5^{\circ} \mathrm{N}, 79.2^{\circ} \mathrm{E}$ ), Ann. Geophys., 24, 823-834: doi:10.5194/angeo-24-823-2006

Steiner A.K., Hunt D., Ho S.P., Kirchengast G., Mannucci A.J., Scherllin-Pirscher B., Gleisner H., von Engeln A., Schmidt T., Ao C., Leroy S.S., Kursinski, E.R., Foelsche U., Gorbunov M., Heise S., Kuo Y.H., Lauritsen K.B., Marquardt C., Rocken C., Schreiner W., Sokolovskiy S., Syndergaard S., Wickert J. (2013), Quantification of structural uncertainty in climate data records from GPS radio occultation, Atmos. Chem. Phys., 13: 1469-1484. doi:10.5194/acp-13-1469-2013

Whiteway J.A., Duck T.J., Donovan D.P., Bird J.C., Pal S.R., Carswell A.I. (1997), Measurements of gravity wave activity within and around the Arctic stratospheric vortex, Geophys. Res. Lett., 24: 1387-1390. doi:10.1029/97GL01322 
Wickert J., Schmidt T., Beyerle G., Konig R., Reigber C., Jakowski N. (2004), The Radio Occultation Experiment aboard CHAMP: operational data analysis and validation of vertical atmospheric profiles, J. Meteorol. Soc. Jpn., 82: 381-395. doi:10.2151/jmsj.2004.381

Wilson R., Hauchecorne A., Chanin M.L. (1990), Gravity wave spectra in the middle atmosphere as observed by Rayleigh lidar, Geophys. Res. Let., 17: 1585-1588.

Wilson R., Chanin M.L., Hauchecorne A. (1991), Gravity waves in the middle atmosphere by Rayleigh Lidar, Part. 1 : Case studies, J. Geophys. Res., 96: 5153-5167.

Wilson R, Chanin M.L., Hauchecorne A. (1991), Gravity waves in the middle atmosphere by Rayleigh Lidar, Part. 2 : Climatology. J Geophys Res., 96: 5169-5183.

Yamashita C., Chu X., Liu H.L., Espy P.J., Nott G.J., Huang W. (2009), Stratospheric gravity wave characteristics and seasonal variations observed by lidar at the South Pole and Rothera, Antarctica, J. Geophys. Res., 114: D12101. doi:10.1029/2008JD011472 